\title{
SOCIAL RESPONSIBILITY OF ECONOMIC ENTERPRISES AS A SOCIAL GOOD: PRACTICE OF THE EU AND UKRAINE
}

\author{
Tetiana Galetska ${ }^{1}$, Natalya Topishko², Ivan Topishko³
}

\begin{abstract}
Current circumstances are shaping new conditions for the interaction of entities of society. The COVID19 coronavirus pandemic tests the partner relationship between government, business and civil society in the system of their social responsibility for the efficiency and morality. The purpose of the study is to reveal the theoretical foundations of the concept of "social responsibility of the state, business, citizen" as a determining factor of formation, self-organization, self-control, modernization of civil society and analysis of the practice of organizing the social responsibility system of economic entities in the EU and in Ukraine. The subject of the research is social responsibility as a fundamental value of society and social institute of regulation of relations in society for ensuring stability of living conditions. The methodology of the research is based on the set of methods of scientific analysis. In particular, dialectical (when characterizing the categorical apparatus of the subject of study); systemic (when analyzing the relationship of socio-economic processes); statistical method of comparisons and groupings; economic analysis (when processing statistics); historical (in the study of the evolution of corporate social responsibility (CSR) theory and practice); empirical (in the analysis of the practice of forming partnerships between business structures, the state and civil society in the European Union and Ukraine). Conclusions of the study. The concept of "social responsibility" is a fundamental value of society, and the system of social responsibility of its entities is a social good. It can be considered as a social institute of socio-economic relations regulation in order to ensure the stability of society and the development of living conditions. The systematization of scientific approaches to defining the social responsibility of economic entities as a social good made it possible to justify it from the standpoint of a public policy object, a system of ethical values of society, voluntary obligations of business and a way of managing a business entity. Features of the current socio-economic situation require strengthening of their socially responsible behavior, introduction and observance of new forms of interaction between business and society on the principles of systematic and longterm. The innovative model of the economy is raising new demands for socially responsible behavior of public relations entities. Models of its realization have their own peculiarities in every EU country. They are all stimulated by state institutional mechanisms (privileges in taxation, subsidies, control over compliance with social and environmental standards); international standards of doing business; control by the public (social reporting to stakeholders). Such institutional levers stimulate the integration of socially responsible behavior into the development strategy of the business structures. The European experience of forming and provision of social positioning of entrepreneurial activity is being studied in Ukraine and is gradually being implemented. The level of transparency of leading companies activities is increasing, especially those, the activities of which are focused on international markets (agribusinesses, energy and metallurgy companies). The lower level of transparency of such information is inherent for mining companies. Transnational companies operating in Ukraine have a higher level of CSR disclosure than domestic organizations. On their websites, twice as often as on websites of the Ukrainian companies, issues on human rights, CSR programs, policies and goals are covered. As the example of the high level of compliance with the CSR principles may serve the activities of the French-Ukrainian company "Verallia-Ukraine" PJSC "Consumers-Sklo-Zorya" (Rivne region, Ukraine). Many Ukrainian business entities have not
\end{abstract}

\footnotetext{
Corresponding author:

${ }^{1}$ The National University of Ostroh Academy, Ukraine.

E-mail: tanya.galetska@oa.edu.ua

ORCID: https://orcid.org/0000-0002-0795-008X

${ }^{2}$ The National University of Ostroh Academy, Ukraine.

E-mail: natalya.topishko@oa.edu.ua

ORCID: https://orcid.org/0000-0001-9823-0805

${ }^{3}$ The National University of Ostroh Academy, Ukraine.

E-mail: ivan.topishko@oa.edu.ua

ORCID: https://orcid.org/0000-0001-7066-5583
} 
yet integrated CSR into their company management strategy. Further promotion of the CSR concept, activation of institutional, economic and social mechanisms for its implementation, evaluation of the effectiveness of its implementation are needed.

Key words: social responsibility, social good, socially responsible business management, models of corporate social responsibility, social partnership, UN Global Compact, international standards of enterprise social reporting, sustainable development.

\section{JEL Classification: A13, M14}

\section{Introduction}

The world is on the verge of major change. In addition to the medical aspects, the COVID-19 coronavirus pandemic will have a negative impact on both the global economy and practically every country. In such circumstances, all issues related to social responsibility and social protection will become increasingly important and relevant.

Social responsibility of the individual, the state, business has always been a significant ethical, socioeconomic and managerial component of the system of the national economy regulation. The role of this social institution is particularly important in today's extremely dynamic environment. The accelerated development of the network (digital, symbolic, high-speed) economy as a new form of social relations significantly transforms the economic and social structure of society, the mechanisms of managing of the national economy, its interaction with the world. The formation of technological paradigm IV and cyber systems creates new technological and socio-economic problems. They affect the employment of the population, its property differentiation, social responsibility of economic entities.

Structural changes that occur under the influence of scientific and technological revolution, innovative economy, globalization increase the instability of society. Social challenges are growing and growing. Issues concerning health, well-being, employment; food and energy security; environment and climate changes; creation of integrated transport; development of innovative and secure society etc. are being updated. Socio-economic processes are becoming unstable. These processes gained unexpectedly acute manifestation in the context of the COVID-19 coronavirus pandemic. In addition to its medical effects, the world is plunged into an economic crisis, with inflation and unemployment rising.

Attention should be paid to the new trend, both in general in socio-economic development, and in matters of social protection and social responsibility. While there has been a tendency towards universalisation over the past few decades simultaneously with the increasing regulatory role of supranational and supranational institutions, there is now a clear tendency to strengthen the role of nation-states, including manifestations of protectionism. Therefore, it is possible to predict the widening differences in models of different countries. Therefore, the relevance of this issue will be enhanced.

Developmental contradictions cannot be solved solely on the basis of market mechanisms. It is important to ensure the regularity of social processes by aligning the interests of economicentities and society, achieving certain priorities to prevent the accumulation of deformities and balance social proportions. In this aspect the problem of social responsibility of all participants of social relations for the formation of a favorable environment of being becomes of particular importance. In revealing the essence of the category "social responsibility", it is important to emphasize primarily on its characterization as a social good, which ensures the systematic of socioeconomic relations. It is a mechanism of social control and balancing of personal, collective and public interests in order to form normal living conditions of their carriers, stable dynamics of the country's development.

\section{Evolution and diversity of social market economy concepts}

The revision of the social doctrine took place gradually under the influence of global competition, liberalization of the economy, migration of capital, introduction of the digital economy, strengthening of the role of transnational corporations, periodic crisis states of national economies. The beginning of this process was laid in the conditions of increased liberalization of the economies of the world's developed countries in the crisis of the 1970s. At that time, public funding for social programs was falling. The principles of paternalism regarding the social expectations of the population were revised. Preference was gradually given to the priority of economic efficiency over the principle of social justice, which had previously dominated in the realization of the "welfare state" concept. The concept of corporate social responsibility was forming. The criteria for its socially responsible behavior were increasing. The parameters of the social component of entrepreneurial activity were determining. Changes were made to the system of social and labor relations and the distribution of authorities between the entities of social partnership. Realization of these principles in economic practice was aimed at ensuring profit as a result of not only its operating function, but also of expanding the range of duties of ethical and social nature. The achievement 
of commercial success of business entities has been increasingly linked to the degree of their participation in solving social problems of society. This has helped to preserve and enhance the degree of coherence of the actions of individuals, business structures and society as a whole in maintaining the living conditions.

Research of modern systemic shifts has been carried out in the scientific achievements of economists with world-famous names (L. Brown, D. Henderson, P. Ekins, R. Norgaard, J. Stiglitz, P. Hawkins, etc.). Representatives of the school of economic sociology (G. Tarde, E. Durkheim, M. Weber, T. Parsons, N. Smelser) developed the theoretical foundations of the concept of motivated, value-oriented behavior of the entities of society. Parsons' social action theory contributed to the discovery of the so-called "law of functioning of social organizations", the development of mechanisms for creating conditions for the mutual orientation of partners, regulation of their behavior by ethical values and norms.

The significant place was given to behavioral element by M. Granovetter, A. Etzioni, M. Castells, R. Swedberg, A. Sen, R. Hollingsworth, Ph. Schmitter, W. Streeck and other scientists. They analyzed the impact of socioeconomic and cultural factors on the organization of production. Eminent political scientists and sociologists devoted their works to the problems of social responsibility, among them there were I. Wallerstein, K. Popper, T. Piketty, D. Acemoglu, J. Robinson, etc. (Feshchenko, 2016).

The latest trends in social development are reflected in numerous theories, namely: concepts of "social wellbeing"; "human development"; "social responsibility of business" by M. Porter and M. Kremer; "Expanding the choice" by A. Sen; "social flow" and "social space" by M. Castells; "risk society" by U. Beck and A. Giddens; R. Florida's creative class; socio-ecological-economic theory of sustainable development; the concept of a "new global thinking” by J. Forrester; J. Stiglitz's "global social justice society"; "the limits to growth" by D. Meadows; E. Laszlo's "new humanism"; the theory of "collective action" by M. Olson and other scientific studies.

The development of scientists has contributed to the evolution of paradigmatic approaches to many notions, in particular, such notions as "entrepreneurship" and "welfare". The theoretical and methodological foundations of the concept of "national welfare", its role in socio-economic development are devoted works of P. Aghion, R. Barro, J. Becker, J.Galbraith, D. Rodrik, S. Rosefield, A. Sen, R. Solow , J. Stiglitz, P. Todaro, F. Fukuyama, and other scholars. Well-being is a measure of the quality of life and the form of fulfilling of people needs, the conditions of their inclusion in the system of social production. D. Acemoglu and J. Robinson, in their study "Why nations fail", emphasized that the condition of its maintaining and grows is efficiency of social and economic institutions of society (mechanisms, rules, rules, regulations, incentives) (Acemoglu \& Robinson, 2016). The effectiveness of such institutions depends on the nature of political institutions that determine the distribution of power and property, the motives of people and business structures.

A new institutional evolutionary and cyclical information and innovation paradigm has been adopted as a modern basis for national welfare research. Its bases are "three components: quality of population (health and education), self-sufficiency (income and employment), basic environmental / living conditions: natural (degree of pollution) and social (provision of basic services, security, degree of human rights realization etc.)” (Kolyadych, 2016).

Various aspects of the social responsibility of economic entities are considered in the context of the paradigm and strategy of sustainable development as its basis. Prominent contributions have been made by such prominent scientists as: F. Ackerman, M. Albert, P. Bauer, S. Wartick, D. Votaw, D. Wood, P. Drucker, J. Elkington, A. Carroll, P. Kotler, P. Cochran, M. Kramer, D. Swanson, S. Sethi, W. Frederick, F. Hayek, W. Hoyer and others.

This issue is being actively developed in Ukraine. The formation of its conceptual and holistic foundations, the adaptation of world experience to the realities of the Ukrainian economy were facilitated by the works of M. Bukovynska, O. Hrishnova, A. Kolot, A. Zinchenko, V. Osetskyi, S. Mochernyi, M. Saprykina, A. Chukhno. Features of CSR implementation by transnational companies were investigated in the scientific publications of V. Mazurenko, M. Kiriakova, I. Iksarova. Qualitative and quantitative aspects of this issue were considered in the publications of O. Berezina, V. Yevtushenko, N. Kovalchuk, S. Levytska, O. Oliynyk, N. Tovma. The problems of improving the methodology of planning, accounting, control of measures and means for providing CSR were reflected in articles of V. Rovenskaya, A. Berzhanir, G. Chirva. The analysis of the relationship of CSR with the general policy of the state was carried out in the scientific works of L. Barannyk, L. Boyko, M. Karlin.

The search for new paradigms of social development, the development of tools for the organization and interaction of economic actors remains a relevant topic of research, the practice of its formation and adherence. Adaptation in the society of the ideas of social responsibility in business models, development and introduction of new models of social interaction, positive practice of dialogue between business and society becomes a time requirement.

\section{Theoretical principles of social responsibility as a social good and social institute}

The category of "social responsibility" is a complex notion that reflects the fundamental values of society. 
Responsibility is considered in terms of dependence on someone or something, ability and willingness to perform moral and spiritual obligations and legal norms (Kolot, 2013). Social responsibility is considered to be a "voluntary management paradigm based on the consideration of social and environmental determinants of development” (Ovsyanyuk-Berdadina, 2019).

This remedy and motive for the internal regulation of the activities of public relations entities have always been regarded as a significant social good. The content of the category "social good" reflects the basic principles, the highest values and norms of understanding of human being. The concept of "good" is an ethical category that is used as a determinant and an important methodological tool for analyzing reality. The common good is regarded as the highest moral criterion for evaluating the actions of the entities of society, the system of its values and the hierarchy of goals as a result of its legislative and regulatory organization. In the political and economic spheres, the concept of the "common good" refers to the problem of social goods and the principles of their distribution among citizens.

In studies of social problems, L. Barannyk says, "scientists often identify the concepts "social" and "public" without defining the differences between them" (Barannyk, 2011). First of all, it is necessary to emphasize the multidimensional concept of "social" (Barannyk \& Datsenko, 2019). The term "social" is interpreted broadly and narrowly. In a broad sense, it refers to "society in general as opposed to nature and is synonymous with public". In the narrow-minded approach, it is "a method of interaction between social groups, strata and individuals as representatives of groups, strata, communities, their position and role in society" (Korolova, 2015, p. 53). The concept of "social good" expresses the degree of coherence of actions of individuals, business structures and society as a whole concerning maintaining of living conditions, reducing of the impact adverse factors on them.

The categories "social responsibility" and "social good" are interrelated. The moral requirements are their ethical underpinnings. Just like the concept of "social good", the category "social responsibility" is not clearly defined, because it reflects the system of values of society. It is broadly interpreted as a set of different interrelated responsibilities (legal, moral, economic, political, professional, etc.). Political scientists' attention is focused on the social responsibility of the state. Economists emphasize on the social responsibility of business for the consequences of economic activity. Lawyers insist on legislative regulation of obligations and sanctions for non-compliance with established norms as social regulators. Philosophers prefer ethical aspects: freedom, morality, duty, behavior. A narrow approach requires determining the extent, to which the entity accepts the socially important goals of society. The readiness for such actions is manifested in compliance with social norms. It has no clear regulation, it is not a means of coercion, it has arbitrary forms. It can be a motivational and limiting factor of the activity.

Vital activity of society is multi-faceted. The system of its management must take into account the interdependence of the individual, the state and business structures. Mutual responsibility is a social mechanism for reconciling their interests. The content and levels of responsibility depend on the place of society's entity in its social hierarchy. The citizen is responsible for the consequences of his or her own actions. The state is responsible for the formation of a favorable macroeconomic environment, definition of strategic goals of country's development. Business structures are responsible for the effectiveness of management decisions, their impact on the development of the organization and society. Significant influence on this process is carried out by the peculiarities of the enterprise's sectoral affiliation, goals of its activity, size and location, participation in international business, ethical principles of company owners, etc.

The idea of socially responsible behavior of economic entities is gradually becoming the basis of public consciousness. It has become a significant message for business in formulating strategies for its activities. Today, as a rule, the concept of "corporate social responsibility" refers to the responsibility of business for all entities of society (partners, consumers, employees of the company, etc.) (Kovban \& Kohut, 2019).

The stages of its development and implementation in projects and programs are reflected in the concepts of corporate social responsibility (CSR) (Kolot, 2013). In 1950-1970s, H. Bowen (Bowen, 1953), K. Davis (Davis, 1960), A. Carroll (Carroll , 1991) developed the basic concept of "corporate social responsibility". It underpinned the concept of "corporate social responsiveness", which was formed in 1970-1990s by R. Ackerman (Ackerman, 1973), A. Carroll (Carroll, 1991), W. Frederick (Frederick, 1986). The necessity to meet the requirements of sustainable development is reflected in the concept of "corporate social performance” (CSP). Significant achievements in its development in the 1980-2000s were made by the works of S. Sethi (Sethi, 1975), A. Carroll Carroll (Carroll, 1991), S. Wartick (Wartick, 1985) D. Wood (Longsdon \& Wood, 2002), etc.

They became the basis for modern theories focused on strengthening of the social mission of business structures:

- "corporate accountability" (report on non-financial activities of the organization, social status of labor resources, etc.);

- "stakeholders" (employees, buyers, shareholders, suppliers, territorial communities, the public, media, state and district authorities, environmentalists, etc.); - "voluntary" concept (the obligation of the entity to strive to achieve long-term goals, in which society is interested); 
- "proactivity" (as a means of responding to contemporary challenges);

- "corporate citizenship" (the activity of the organization is related to the realization of the rights and duties of individuals);

- "corporate sustainability" (assesses the social and economic impact of the organization on the internal and external environment. New business strategies are developed from the standpoint of sustainable development ideas (the so-called "triple bottom line": the triple goal of sustainable development for business) by J. Elkington (People, Planet, Profits)” (Elkington, 1999);

- "blended value". Targeting business methods and goals for both profit and social value and related revenue (Transforming our world: the 2030 Agenda for Sustainable Development, p. 42), (Zinchuk \& Levkivskyy, 2019).

Corporate social responsibility is focused on the internal and external environment (Popadyuk \& Luchyk, 2019). In the internal environment, it is mainly focused on employees, increasing productivity and improving professional standards, protection and safety of work, compliance with the requirements of labor law, the implementation of social programs. It is emphasized on the importance of propely paid taxes and production of quality products. Its effectiveness depends on the efficiency of economic activity and the scale of the enterprise, the policy in the sphere of remuneration and the organization of social and labor relations. As a rule, the consequence is to increase the reputation of the company, to create a safe environment, to increase the confidence of stakeholders.

The external component of corporate social responsibility concerns compliance with ecological principles of production activity, ensuring quality standards of production, interaction with local communities and assistance in crisis situations, sponsorship and charity, participation in national socioeconomic programs. The result is the formation of a safe environment of being, adherence to international norms and standards of socially responsible behavior, enhancing of the company reputation. The external component is not governed by applicable law. It is clearly vague and therefore contradictory. Its features significantly depend on the goals of the organization, its location, the specifics of the industry.

The assessment of the effectiveness of the social activity of the company, its monitoring and control is carried out by a system of indicators, which are divided into three groups. The first are indicators of social responsibility to employees: working conditions, remuneration, bonuses, hours worked overtime, staff turnover, training and learning outcomes, gender and age workforce structure, number of workers with disabilities, number of workplace incidents, evaluation of the company by employees. The second are environmental indicators: the impact on the environment and its costs, the use of secondary raw materials, energy consumption and energy efficiency, waste management, the number of penalties for non-compliance with environmental standards. Third are indicators of company behavior on the market: customer complaints, complaints about unfair advertising, penalties from the Antimonopoly Committee, providing consumers with better service, etc. (Ivanytska, 2015).

Therefore, social responsibility has many aspects: political, moral, legal, economic. It has its dimension. It is the degree of fulfillment by the entity of his or her rights and obligations, the acceptance of socially important goals of society by him or her, the recognition of the principles of social justice, the consent to pay high taxes to meet public needs and social protection. Adherence to its principles reflects the balance achieved in society with respect to the needs of the population and the agreement of business structures and the state to provide them. Other factors also play a significant role. In particular, the degree of state regulation and the perfection of the institutional environment; the development and strength of influence of civil society; state and strategic priorities of socio-economic development of the country; work and business ethics of economic activity; traditions, national and religious values of the society; politics, law, culture; public priorities; management ideology.

\section{The European practice of formation and realization of corporate social responsibility}

Depending on the role of the state and the mechanism of interaction between the entities of social relations, the degree of voluntariness to implement social programs is conditionally distinguished three models of social responsibility: the American, European and Asian (Japanese). Some authors extend their composition to seven or more: American (US), European (Continental), British, Scandinavian, Asian (Japanese), African, BRICS models, etc. (Kovban \& Kohut, 2019).

In the liberal American model (USA, Canada, the English-speaking states of Africa and Latin America), government intervention in the economy is limited. Social responsibility is realized mainly in the form of charity, philanthropy, volunteering on a voluntary basis and principles of moral obligation of owners, management of companies. Public business activity is encouraged by the government in the form of tax cuts and supported by the public. In the Japanese model, the focus is on the internal environment of the company. The role of the state is significant. The policy of equalization of incomes of the population is being implemented. A high level of collectivism is inherent in the solution of socio-economic problems.

The European model of social responsibility is embodied in two forms: Continental and Anglo-Saxon. 
The model of Central Europe (Austria, Germany, France) has a high degree of state regulation of social and labor relations while preserving the broad independence of enterprises and trade unions. The Northern European model (Belgium, Norway, Sweden) is based on active state regulation of social and labor relations at all levels (individual, business, state). The economic goals of the company should be in line with the socio-economic and political interests of the stakeholders and the society as a whole. The UK (AngloSaxon) model combines elements of the American (high degree of voluntary behavior of companies in this area) and the continental European model (government incentives and regulatory actions to formulate behavioral strategies). The European model focuses on economics, employment and the environment.

The dynamic changes of the modern world have contributed to the modification of models of economic activity. They encourage a change in the structure of the economy, governance mechanisms, the development of effective strategies for action and competition. Indicators of successful business models and competitive advantages are new production and market entry technologies, new management methods, and highly qualified personnel. At the same time, social risks are increasing. States have limited capacity to ensure a stable socio-economic dynamic. Under these conditions, the social dialogue of business and society is given particular weight in developed countries.

At the beginning of the 21st century, most European countries had a nearly balanced system of benefitsharing and financial burden-sharing in society. The state retains responsibility for socio-economic development. In Europe, socially responsible company behavior is integrated into a coherent socio-economic policy and regulated by the state. The criteria for socially responsible business are honest tax payment; compliance with the requirements of international and national legislation; production of quality products; development of company social programs; participation in social projects of regional and general scale; environmental protection; charity projects etc. Adherence to the principles of social responsibility becomes a priority of the individual, the state and business.

Promotion of the ideas of social responsibility of the European companies was acselareted by creation "The European Business Network - CSR Europe” (European Business Network) in 1995. Adopted in 1997, the Global Reporting Initiative to develop standards for corporate social (non-financial) reporting has become a benchmark for CSR in Europe. Its further development was facilitated by the Global Compact (2000) (UN Global Compact). The Global Compact sets out ten basic principles of corporate social responsibility. The procedures and practices of conducting socially responsible business (organizational management, human rights, labor relations, ethical operations, environmental protection, consumer protection, development of territorial communities and cooperation with them) are outlined. The forms of preparation of social (non-financial) reporting of the organization are defined. It should reflect the environmental, social, managerial aspects of the company's activity. They are increasingly integrated into the organization's management system.

The adoption of the "Green Paper" program (promoting the European structure of CSR) in 2001 stimulated the development of its strategies, tools and mechanisms by the EU Member States (GREEN PAPER).

Appendices to this document were:

- The "EU Environmental Action Plan". In connection with the preparation of the EU budget for 2021-2027, the European Commission has proposed an increase of almost $60 \%$ of the financing of the EU environmental protection and climate change program - LIFE (5.45 billion EUR budget) (EU Environmental Action Plan);

- The "General Recommendation and Audit System" (EMAS) - Recommended CSR assessment and reporting system;

- The "European Eco-efficiency Initiative" (EEEI) European Expertise and Expert Institute (integration of environmental performance principles into companies' industrial and economic strategic plans);

- The "Integrated Product Policy" ("IPP") - monitoring the degree of environmental impact of production processes, stimulation the introduction of the most efficient production methods;

- The European Parliament resolution "EU Standards for European Enterprises in Developing Countries: Towards a European Corporate Code of Conduct";

- "CSR Europe 2020" Strategy: a strategy for smart, sustainable and inclusive growth (CSR Europe 2020 Strategy);

- "CSR Europe 2030" Strategy. Five key areas of the sustainable development agenda are identified: promoting high environmental, social and governance standards at the international level; the stability of ecosystems by strengthening local communities; impact and change - the focus of the network; implementation of common CSR platforms and value chain; increased transparency and active involvement of stakeholders at all levels (CSR Europe 2030 Strategy).

The CSR policy of governments is based on a number of key European and international documents, namely: (Corporate Social Responsibility \& Responsible Business Conduct) Directive 2014/95/EC on nonfinancial reporting; Communication from the European Commission "Europe 2020: A strategy for smart, sustainable and inclusive growth"; Human Rights and Democracy Action Plan (2015-2019); Communication on the next steps towards a sustainable European future; UN Global Compact; UN Guidelines on Business and Human Rights; UN Agenda for Sustainable 
Development for 2030; ISO 26000 Guideline on Social Responsibility; OECD Guidelines for Multinational Enterprises; OECD Guidelines for Due Diligence for Responsible Behavior; Principles of Social Policy for Multinational Enterprises of the International Labor Organization; OECD Guidance on Good Practice Verification Procedures (CSR Ukraine).

In the EU, state regulation of this process is combined with an active role in promoting corporate social responsibility of intergovernmental structures, in particular the committees of the European Commission (Corporate Social Responsibility, Responsible Business Conduct, and Business \& Human Rights: Progress Overview, 2019).

The components of the international mechanism of formation of socially responsible behavior of entities are the Code of Business Ethics, Declarations, Charters, international standards of social responsibility. These standards are used by transnational corporations, business structures, governments, and civil society. They are based on specific criteria and reflect sustainable development strategies. Governments in Europe are encouraging economic actors to comply with these standards. Large European companies reflect the results of their socially responsible activities (environmental and social performance) in financial and non-financial reporting (Petrashko \& Martynyuk, 2019). Information is used by organizational managers and stakeholders to make decisions.

The world and European organizations pay particular attention to compliance with the international CSR standards as a tool for ensuring the stability of the business environment. The requirements for the set of indicators and the quality of social reporting, the formation of socio-economic and environmental activities of organizations are presented in the GRI (Global Reporting Initiative) series. The system of criteria, principles, guidelines for integrating social programs into the activities of companies and reflecting them in social (non-financial) reporting is the standard AA1000 (Acount Ability). In 2018, a new set of AA1000 (AA1000AR) 2018 Accountability, Responsibility, Reliability, Sustainability and Integrated Stakeholder principles were developed to prioritize and respond to sustainable development issues to improve long-term performance (Acountount Ability, 2019).

ISO-9000 (International Organization for Standardization) standards define the parameters of product quality management. The ISO-14000 series (14010, $14011 / 1,14012$ ) contains environmental management system standards. The ISO 26000 Guidelines on Social Responsibility (ISO / DIS 26000) recommendations for ensuring the effectiveness of socially responsible behavior of organizations of all types and in different countries are given, and the principles of voluntary compliance are formulated. The SA- 8000 (Social Accountabiliti International) standards are designed to develop and adhere to the ILO's recommended work organization systems.

To assess public needs, 100 international corporations are ranked annually. The top ten of such leading companies are listed in Table 1.

Thirty of the fifty internationally socially responsible corporations listed in the "2020 Global 100 ranking" are leading European companies (from France, Denmark, the Netherlands, Germany, Finland, Austria) (Global 100 ranking 2020). The methodology for compiling this rating is provided in "The 2020 Global 100: Overview of Corporate Knights Rating Methodology" (The 2020 Global 100: Overview of Corporate Knights Rating Methodology, 2020).

According to A. Kovban and I. Kohut, social responsibility has become a global business concept that defines key ideas and a modern format for entrepreneurship (Kovban \& Kohut, 2019).

The current situation with COVID-19 is testing the social responsibility policy of all entities of the economy for viability and morality. As practice has

Table 1

Top 10 out of 100 international companies with the best CSR (dated of January 21, 2020)

\begin{tabular}{|c|c|l|l|c|c|}
\hline $\begin{array}{c}\text { Rank } \\
2020\end{array}$ & $\begin{array}{c}\text { Rank } \\
2019\end{array}$ & \multicolumn{1}{|c|}{ Company } & \multicolumn{1}{c|}{ Peer Group } & Overall Score \\
\hline 1 & 4 & Orsted A/S & Wholesale Power & Denmark & $85.20 \%$ \\
\hline 2 & 1 & Chr. Hansen Holding A/S & Food and other chemical agents & Denmark & $83.90 \%$ \\
\hline 3 & 3 & Neste Oyj & Petroleum Refineries & Finland & $83.64 \%$ \\
\hline 4 & 14 & Cisco Systems Inc & Communications Equipment & United States & $83.59 \%$ \\
\hline 5 & 48 & Autodesk Inc & Software & United States & $82.84 \%$ \\
\hline 6 & 58 & Novozymes A/S & Specialty and Performance Chemicals & Denmark & $82.70 \%$ \\
\hline 7 & 35 & ING Groep NV & Banks & Netherlands & $82.53 \%$ \\
\hline 8 & - & Enel SpA & Wholesale Power & Italy & $81.77 \%$ \\
\hline 9 & 8 & Banco do Brasil SA & Banks & Brazil & $81.72 \%$ \\
\hline 10 & - & Algonquin Power \& Utilities Corp & Electric Utilities & $80.89 \%$ \\
\hline
\end{tabular}

Source: Global 100 ranking 2020 
shown, governments and businesses strive to meet the social expectations of citizens. The factors determining the success of the measures taken were the efficiency of the activities of the state structures, their ability at all levels of management quickly execute government decisions and negotiate with the public. Also, the effectiveness of the health care system, the ability and willingness of the population to comply with the restrictions, the willingness of business organizations to suffer short-term decline in profitability to comply with the ethical principles of the company, the ability to retain prepared workforce and production, financial support for their employees. Rigorous quarantine measures in the long term can lead to significant socio-economic problems (bankruptcy of companies, unemployment, etc.). In order to prevent the total poverty of the population, to support the economy and the solvency of the population, the governments of the countries are taking unprecedented measures. Business assistance, payroll, parent payments, cheap loans and tax deferrals are provided at the state expense.

As of April 21,2020, 205 countries and territories were affected by the COVID-19 coronavirus. 2481287 cases were reported (Khronika koronavirusa v Ukraine i mire). To prevent the spread of infection, society is consciously suffering significant economic and social losses. The UK government allocates 39 billion USD to support the most vulnerable categories of population, self-employed persons, the National Health System and the economy. The EU allocates 230 million EUR to combat the COVID-19 pandemic. The Italian government is allocating 25 billion EUR to overcome the emergency. The EU is channeling 7.5 billion EUR to help the hardest hit by COVID-19 countries (Italy, France, Germany). To mitigate the effects of the virus in the affected countries, the IMF spends $\$ 50$ billion, the World Bank - 12 billion USD. In order to prevent the economic downturn, Australia is allocating 11.4 billion USD. Canada has set up a 750 million USD response fund to provide provinces and territories with the prevention and impact of the pandemic (Italiya vydelit 25 mlrd yevro na bor'bu s koronavirusom; Voyna s COVID-19).

In order to overcome the economic downturn, reducing unemployment, countries are taking anticrisis measures to overcome the recession and minimize the effects of the pandemic. Italy offered to issue bonds. The proposal was supported by 11 EU Member States, including France and Spain. However, Germany, Austria and the Netherlands opposed. For this purpose, Estonia has allocated 4 billion USD that can be borrowed from international financial institutions to reduce excise taxes on energy resources, refinance loans, and debt restructuring. Latvia allocates 1.5 billion USD to support small and medium-sized businesses, and installed tax exemption for a year. Lithuanian government provided
3 billion USD on tax benefits to business entities, provided that their jobs are retained (Quarantine on the economy: what anti-crisis measures are taken by other countries?).

\section{Implementation of social responsibility in the strategy of development of the Ukrainian enterprises}

For Ukraine, the experience of the EU countries in coordinating business and civil society action is up-todate and actively studied (Yevropeys'ki biznes-praktyky KSV). Standards of socially responsible business behavior are gradually being introduced into business practices (Saprykina, 2019).

CSR Ukraine, "CSR Development” Center launched a new online course, "Non-Financial Reporting" on Impactorium platform in 2020. Representatives of the Ukrainian companies "Nova Poshta", "Energoatom", "Auchan", "Astarta", "Coca-Cola" provide practical advice on preparation of social (non-financial) reporting. According to a survey conducted by the "CSR Development" Center, in 2018, 13\% of the Ukrainian companies prepared non-financial reports from $78 \%$ of companies globally (CSR Ukraine).

The Center "Corporate Social Responsibility Development" is operating in Ukraine as part of the "Capacity Building of the National Contact Point on Responsible Business Conduct” project, supported by the Embassy of the Netherlands in Ukraine. There is also an advisory Council for the development of the National Concept for the Development of Corporate Social Responsibility, the Community for Corporate Social Responsibility. A national CSR strategy is being developed by the initiative group within the framework of a public platform (120 participants) open to accession.

Business CSR ratings are compiled. The "CSR Development" Center is actively working in this area. The Center presents the results of the annual evaluation of the largest Ukrainian companies for disclosure of CSR on the criteria of the Global Transparency Index (Zinchenko, 2017; Saprykina, 2019).

Table 2 shows the overall results of the Transparency Index for Ukrainian Companies in 2011-2017.

In 2017, the average level of CSR disclosure on the Ukrainian companies' sites remained low - 21.7\% (2013 - 16.9\%; 2014 - 17.1\%) (Zinchenko, Reznik, Saprykina, 2018; CSR Ukraine). According to a 2017 report, out of the 99 companies evaluated, less than half (41 companies) had higher than average disclosure rates. TOP-10 companies include JSC "Myronivsky Plant for Manufacturing Groats and Feeds", DTEK, The State Enterprise "National Nuclear Energy Generating Company "Energoatom", "ArcelorMittal Kryvyi Rih”, PC “Lifecell”, JSC “Naftogaz of Ukraine”, PC "Nova Poshta” SCM, PC "Carlsberg Ukraine" (CSR Ukraine). Among TOP-10 - 3 state- 
Table 2

Overall results of the Ukrainian Companies Website Transparency Index

\begin{tabular}{|c|c|c|c|c|c|c|}
\hline Name of the company & $\begin{array}{l}\text { Place } \\
2011\end{array}$ & $\begin{array}{l}\text { Place } \\
2012\end{array}$ & $\begin{array}{l}\text { Place } \\
2013\end{array}$ & $\begin{array}{l}\text { Place } \\
2014\end{array}$ & $\begin{array}{l}\text { Place } \\
2017\end{array}$ & $\begin{array}{l}\text { Score } \\
2017\end{array}$ \\
\hline JSC "ArcelorMittal Kryvyi Rih" & 4 & 4 & 2 & 1 & 4 & 71 \\
\hline DTEK & 1 & 2 & 1 & 2 & 2 & 79 \\
\hline SCM & 5 & 1 & 3 & 3 & 9 & 46 \\
\hline JSC “OBOLON” & 3 & $\begin{array}{c}- \\
\text {-in } 2011-3\end{array}$ & 4 & 4 & 31 & 25 \\
\hline PC "Metinvest" & 2 & 3 & 5 & 5 & 11 & 46 \\
\hline PC "Carlsberg Ukraine" & -- & - & 6 & 6 & 10 & 46 \\
\hline JSC "Kyivstar" & 6 & 5 & 7 & 6 & 23 & 28 \\
\hline PC “ОККО Group” (Concern Galnaftogaz) & - & - & 10 & 8 & & \\
\hline JSC “Dneprospetsstal” & - & 8 & 9 & 9 & - & - \\
\hline Kraft Foods Ukraine (Mondelēz International) & 31 & 17 & 20 & 10 & - & - \\
\hline
\end{tabular}

Source: Zinchenko, Reznik, Saprykina, 2018; Koval'chuk, 2017

owned companies: JSC "Naftogaz of Ukraine, The State Enterprise "National Nuclear Energy Generating Company "Energoatom", and The State Enterprise "Energoatom". The average TOP 10 disclosure rate is $62.3 \%$. Out of 10 leading companies, 8 companies have prepared and posted non-financial reports on their sites. The average CSR disclosure score was 35.6 out of 55 possible. This is almost three times higher than other companies.

In 2017, only 16 Ukrainian companies from the top 100 were placed on corporate sites their non-financial reports. Two of them are state-owned companies (in 2014 the level of openness of state-owned enterprises was $12.8 \%$. The index of private companies was slightly higher). Only five companies have integrated Sustainable Development Goals into their non-financial statements, including PC "Carlsberg Ukraine".

Information on significant aspects of CSR disclosed by the Ukrainian companies on its corporate sites is insufficient ( 12.8 out of 55 points). The practice of labor relations, development and support of communities, environmental protection is mainly covered. Issues of remuneration to management, programs of CSR implementation in the supply chain, responsible marketing policies, and results of CSR activities are poorly covered. They are mainly measured only by the companies that prepare the reports. However, they do not always provide this information in the relevant sections of the site.

A positive development in CSR in Ukraine is the increase in companies that develop and implement anti-corruption and compliance policies (compliance with any internal or external requirements or norms), programs of implementation of CSR in the supply chain. The level of transparency of activities of agribusinesses, energy and metallurgy companies has increased. The lowest level of transparency was observed in mining companies. Public companies, more often than private ones, cover anti-corruption policy (adoption and promulgation of anti-corruption policy is a requirement of the law). Private companies are more likely to raise concerns about community development and protection of the environment. International companies have a higher level of CSR disclosure. Compared to the Ukrainian companies, international corporations' websites are twice as likely to cover issues of human rights, programs and policies for CSR implementation in the CSR supply chain and CSR objectives (Zinchenko, Reznik, Saprykina, 2018; CSR Ukraine).

An example of adherence to CSR principles could be the activities of the French-Ukrainian company "Verallia-Ukraine" of Private Joint Stock Company "Consumers-Sklo-Zorya" (Rivne region, Ukraine). It belongs to the French company "Saint-Gobain", which is part of the group of one of the world's largest manufacturers of glass products "Saint-Gobain Packaging” (Canada). The company produces glass packaging for food and beverages. It is the market leader in Ukraine. The products are shipped to Poland, the Czech Republic, Lithuania, Romania, Germany, France, Italy and other countries. The main product market is the European ( $53 \%$ of sales) and Ukrainian $-47 \%$.

The company is a member of the UN Global Compact and strives to pursue sustainable development goals. In the 2019 report on social responsibility of company (PJSC "Consumers-Sklo-Zorya"), it is emphasized that the mission of the company is in line with Verallia's 4 values: customer care, respect for the people, compliance with the law and a careful attitude towards the environment, awareness of responsibility and result orientation, teamwork. Accordingly, the Company's commitments under the CSR initiative are built around three main areas: promoting environmental protection; 
actions on the security and development of its teams; promoting community development.

The main directions of its activity in this field are identified. In particular, to set an example for managing the environmental impact of an enterprise; development and protection of the company's human capital; participation in the economic and social development of the community. The company has formed a fairly high number of competitive advantages. The ethical values of the company are proclaimed as follows: dedication to its business; respect for people; honesty, loyalty, solidarity; compliance with the law; reduction of harmful effects on the environment; observance of the rules of health and safety at work, ensuring the rights of employees; involvement of employees in daily compliance with standards and principles. The company sees its mission as a responsible economic partner in the development of innovative solutions that meet humanity's global needs for development, energy conservation and ecology. The company's management strives to ensure a high level of both economic performance and human capital development. Attention is drawn to the lack of comments on product quality and processing of all production wastes; prevention of all forms of risks, accidents, occupational diseases. The enterprise strategy is based on research and prevention activities. Favorable conditions are created for the dissemination of knowledge and professional skills, there are training modules for all categories of employees, programs for upgrading the skills of staff.

Corporate Social Responsibility is implemented by the company both internally and externally. The company's stakeholders are its partners, investors, customers, suppliers, community. Since 2012, social networks have been used for communications. "Verallia" adheres to international standards of production and quality, in particular, environmental control (ISO 14001); quality (ISO 9001); energy use (ISO 50001); food security (ISO 22000), the health and safety of the employees (OHSAS 18001).

"Verallia-Ukraine" Private Joint Stock Company "Consumers-Sklo-Zorya" carries out permanent charitable activity. Arrange it to increase the level of concretization, prompt and transparent implementation of financial transactions. Four programs of assistance to children are being implemented: "Rozhevi shchichky" (feeding children with health defects in four children's boarding schools in the village of Klevan, Rivne District); "Sonechko" (provision of boarding schools with heat, clothing, shoes); "Viterets'" (funds for children's health improvement); "Veselka" (activities for organizing children's leisure). "Verallia" constantly pays attention to establishing cooperation with the community. It is an example of socially responsible behavior based on the interests of consumers, stakeholders and society. Certainly, large enterprises have advantages in the organization of corporate social responsibility. These issues are dealt with by managers.
In Ukraine, socially responsible business is in its infancy. Forms of its manifestation are social partnership, charity, social dialogue. A growing number of companies are gradually and voluntarily integrating social responsibility into a systematic business strategy. For the implementation of social responsibility prevents the lack of unified standards of social responsibility of the company; weak economic position of most business entities in Ukraine; confidentiality of information of most business structures; low level of corporate culture; insufficient development of charitable and social activities of state and non-governmental organizations. The situation was complicated by the effects of the COVID-19 coronavirus pandemic.

\section{Conclusions}

In modern conditions, there is a systemic and profound transformation of socio-economic relations. It is due to the rapid development of scientific and technological progress on the basis of the fourth industrial revolution, the creation of artificial intelligence, an economy of Industry 4.0. The technological way of life, the labor market, living space, life of the population, etc. are undergoing changes. A fundamentally new foundation of productive forces is being formed. Information and computer technologies have accelerated the process of creating a network economy and network society. In today's difficult conditions there is a change in the structure of the economy, governance mechanisms, development strategies and competition. These trends are exacerbated by the COVID-19 coronavirus pandemic, which has prompted the accelerated transfer of business activity from all economies to the Internet. Therefore, socio-economic processes need to be considered in three temporal dimensions: before the pandemic, during it and forecasts for the future.

Although, the choice of a certain behavior of the subjects of society is a form of realization of its social and economic freedom, its regulation by social norms depends on the decisive influence on this process of state institutions, the level of responsibility of socio-economic and political life. Therefore, social responsibility is a social good and a complex concept that reflects the fundamental values of society, ensures the system of socio-economic relations, concentrates understanding of social values, ethical principles of behavior of social partners, the strategy of society.

The current socio-economic situation with COVID-19 actualizes the search for the principles of non-conflict interaction of business, state and society. It is necessary to further popularize the concept of CSR, intensify the institutional, economic, social mechanisms of its implementation, assess the effectiveness of implementation in new crisis conditions that are changing at lightning speed. 


\section{References:}

Ackerman, R. W. (1973). How Companies Respond to Social Demands. Harvard Business Review, vol. 51(4), pp. 88-98.

Acountount Ability. Retrieved from: https://www.accountability.org/standards/licensing/2019-aa1000asreports/

Ajemoglu, D., \& Robinson, J. (2016). Why Nations Decay / Trans. from English: O. Demianchuk. Kyiv: Our format.

Barannyk, L. B. (2011). "Sotsial'ne blaho" yak klyuchova katehoriya sotsial'noho zakhystu naselennya: teoriya i real'nist' "Social good" as a key category of social protection of the population: theory and reality]. Naukovi zapysky Natsional' noho universytetu "Ostroz' ka akademiya", vol. 16, pp. 249-255.

Barannyk, L. B., \& Datsenko, V. V. (2019). Sotsial'nyy kapital: pytannya teoriyi ta praktyky [Social capital: issues of theory and practice]. Naukovyy pohlyad: ekonomika ta upravlinnya, vol. 1(63), pp. 160-165.

Bowen, H. R. (1953). Social responsibilities of the businessman. New York: Harper \& Row

Carroll, A. B. (1991). The pyramid of corporate social responsibility: toward the moral management of organization stakeholders. Business Horizons, vol. 34(4), pp. 39-48.

Commission Staff Working Document. Corporate Social Responsibility, Responsible Business Conduct, and Business \& Human Rights: Progress Overview (2019). EUROPEAN COMMISSION, 20.3.2019 SWD (2019). Retrieved from: https://ec.europa.eu/docsroom/documents/34482

CSR Europe 2020 Strategy. Retrieved from: https://www.csreurope.org/enterprise-2020-manifesto

CSR Europe 2030 Strategy. Retrieved from: https://www.csreurope.org/about-us/our-2030-strategy

CSR Ukraine. Retrieved from: http://csr-ua.info/csr-ukraine/

Corporate Social Responsibility \& Responsible Business Conduct. Retrieved from: https://ec.europa.eu/growth/ industry/corporate-social-responsibility_en

Davis, K. (1960). Can business afford to ignore social responsibilities? California Management Review.

Elkington, J. (1999). Cannibals with Forks: The Triple Bottom Line of 21st Century Business. Hoboken, New Jersey: John Wiley \& Son Ltd.

EU Environmental Action Plan. Retrieved from: https://eu-ua.org/novyny/yes-zbilshuye-finansuvannyaprogramy-life-iz-zahystu-dovkillya

Feshchenko, V. M. (2016). Suchasni ekonomichni teoriyi: kontseptual'ni vytoky ta evolyutsiya zmistovnoho napovnennya [Modern economic theories: conceptual origins and evolution of content filling]. Zbirnyk materialiv Vseukrayins'koho kruhloho stolu "Suchasni ekonomichni teoriyi: istoriya, metodolohiya ta perspektyvy rozvytku". Kyiv: KNEU.

Frederick, W. C. (1986). Toward CSR-3: Why Ethical Analysis is Indispensable and Unavoidable in Corporate Affairs. California Management Review, vol. 18(2), pp. 126-141.

Global 100 ranking 2020. Retrieved from: https://www.corporateknights.com/reports/2020-global-100/2020global-100-ranking-15795648/

GREEN PAPER: Promoting a European framework for Corporate Social Responsibility. Retrieved from: https://ec.europa.eu/commission/presscorner/detail/en/DOC_01_9

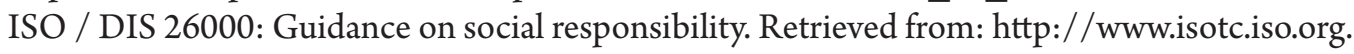

Ivanyts'ka, O. (2015). Hlobal'ni standarty sotsial'noyi vidpovidal'nosti biznesu [Global standards of corporate social responsibility]. Nezalezhnyy audytor, vol. 5-6, pp. 40-41. Retrieved from: http://n-auditor.com.ua/uk/ component/na_archive/1241?view=material

Italiya vydelit $\overline{25} \mathrm{mlrd}$ yevro na bor'bu s koronavirusom [Italy will allocate 25 billion euros to fight against coronavirus]. Retrieved from: https://finance.liga.net/ekonomika/novosti/italiya-vydelit-25-mlrd-evro-naborbu-s-koronavirusom

Khronika koronavirusa v Ukraine i mire [Chronicle of coronavirus in Ukraine and the world]. Retrieved from: https://news.liga.net/incidents/chronicle/novyy-koronavirus-v-kitae-vse-glavnye-novosti

Kolyadych, O. I. (2016). Zminy v zhorstkomu yadri teoriyi dobrobutu na pochatku XXI st. [Changes in the hard core of the theory of well-being at the beginning of the XXI century]. Zbirnyk materialiv Vseukrayins'koho kruhloho stolu "Suchasni ekonomichni teoriyi: istoriya, metodolohiya ta perspektyvy rozvytku". Kyiv: KNEU.

Kolot, A. (2013). Suchasna filosofiya korporatyvnoyi sotsial'noyi vidpovidal'nosti: evolyutsiya pohlyadiv [Contemporary philosophy of corporate social responsibility: the evolution of views]. Ukrayina : aspekty pratsi, vol. 8, pp. 3-17.

Korol'ova, Yu. V. (2015). Dzherela prava v aspekti yikh sotsial'noho vymiru [Sources of law in the aspect of their social dimension]. Derzhava i pravo, vol. 67, pp. 51-59.

Koval'chuk, V. (2017). Reytynhy z korporatyvnoyi sotsial'noyi vidpovidal'nosti yak instrument pidvyshchennya konkurentospromozhnosti pidpryyemstv [Corporate Social Responsibility Ratings as a Tool for Increasing the Competitiveness of Enterprises]. Naukovyy pohlyad: ekonomika ta upravlinnya, vol. 1(57), pp. 82-89. Retrieved from: http://scientificview.umsf.in.ua/archive/2017/1_57_2017/12.pdf 
Kovban, A., \& Kohut, I. (2019). Formation of a corporate social responsibility strategy of companies in EU countries. Baltic Journal of Economic Studies, vol. 5, no. 3, pp. 82-90. doi: 10.30525/2256-0742/2019-5-3-82-90

Longsdon, J., \& Wood, D. (2002). Business Citizenship: From a Domestic to a Global Level of Analysis. Business Ethics Quarterly, vol. 12(2), pp. 155-187.

Nastanova OESR stosovno protsedur nalezhnoyi perevirky u praktytsi vidpovidal'noho (2018). [The OECD institution is relevant procedural inspection procedure in responsibility business]. Retrieved from: http://csr-ua.info/csr-ukraine/wp-content/uploads/2019/07/DD-ua web-2.pdf

Ovsyanyuk-Berdadina, O. F. (2019). Sotsializatsiya biznesu: suspil'ni ta rynkovi proyavy [Socialization of business: social and market manifestations]. Naukovyy pohlyad: ekonomika ta upravlinnya, vol. 1(63), pp. 48-53.

Petrashko, L., \& Martynyuk, O. (2019). Yevropeys'ki biznes-praktyky korporatyvnoyi sotsial'noyi vidpovidal'nosti: keysy [European Corporate Social Responsibility Business Practices: Case Studies]. Kyiv: KNEU.

Popadyuk, O. V., \& Luchyk, O. I. (2019). Pryntsypy ta mekhanizm sotsial'noyi vidpovidal'nosti v umovakh stratehichnoho upravlinnya pidpryyemstvom [Principles and mechanism of social responsibility in terms of strategic enterprise management]. Ekonomika ta upravlinnya pidpryyemstvamy, vol. 36, pp. 235-245.

Private Joint Stock Company “Consumers-Sklo-Zorya”. Retrieved from: https://csr.verallia.com/en/pdf_2019/ mobile/index.html

Quarantine on the economy: what anti-crisis measures are taken by other countries? Retrieved from: http://razumkov.org.ua/comments/karantynom-po-ekonomitsi-iaki-antykryzovi-zakhody-pryimaiut-inshi-krainy

Saprykina, M. (2019). Praktyku KSV v Ukrayini. [CSR Practices in Ukraine]. CSR Development Center, Kyiv.

Sethi, S. (1975). Dimensions of Corporate Social Performance: An Analytic Framework. California Management Review, vol. 17(3), pp. 58-74.

The 2020 Global 100: Overview of Corporate Knights Rating Methodology. Retrieved from: https://www.corporateknights.com/wp-content/uploads/2020/03/2020-Global-100_Methodology.pdf

Transforming our world: the 2030 agenda for sustainable development (n.d.). Retrieved from: http://www.un.org/ga/search/view_doc.asp?symbol=A/70/L.1\&Lang=E

UN Global Compact. Retrieved from: www.mlsp.gov.ua/.../article\%3Bjsessionid=07E30561B5BF4DDE28B50

Voyna s COVID-19. Kakiye summy raznyye strany napravili na bor'bu s koronavirusom [War against COVID-19. What amounts have different countries used to fight against coronavirus?] Retrieved from: https://finance.liga.net/ ekonomika/novosti/vlasti-raznyh-stran-vydelyayut-bespretsedentnye-summy-na-borbu-s-koronavirusom

Wartick, S. L. (1985). The evolution of the corporate social performance model. Academy of Management Review, vol. 10(4), p. 758.

Yevropeys'ki biznes-praktyky KSV [CSR European Business Practices]. Retrieved from: http://www.csr-eu-jm.com.ua/ files/CSR-research-ukrainian.pdf

Zinchenko, A. (2017). Rozvytok KSV v Ukrayini: 2010-2018 [CSR Development in Ukraine: 2010-2018]. Kyiv: Juston, 52. Retrieved from: http://csr-ua.info/csr-ukraine/wp-content/uploads/2018/10/CSR_2017_reserch-1.pdf Zinchenko, A., Reznik, N., \& Saprykina, M. (2018). Indeks prozorosti saytiv ukrayins'kykh kompaniy - 2017. [Transparency Index of Ukrainian Companies' Sites - 2017]. Kyiv: Vydavnytstvo "Yuston”. Retrieved from: http://csr-ua.info/csr-ukraine/wp-content/uploads/2018/10/Transp_Index_2018_preview-.pdf

Zinchuk, T. O., \& Levkivs'kyy, Ye. V. (2019). KSV vertykal'no intehrovanykh struktur ahrarnoho biznesu yak umova staloho rozvytku [CSR of vertically integrated structures of agrarian business as a condition of sustainable development]. Ekonomika APK, vol. 1, pp. 39-49. 